\title{
Combined nutrient-toxicant effects on a shallow-water marine sediment system: sensitivity and resilience of ecosystem functions
}

\author{
Kristina Sundbäck ${ }^{1, *}$, Dorthe Groth Petersen ${ }^{1,2}$, Ingela Dahllöf ${ }^{2}$, Fredrik Larson ${ }^{1}$ \\ ${ }^{1}$ Department of Marine Ecology, Marine Botany, Göteborg University, PO Box 461, 40530 Göteborg, Sweden \\ ${ }^{2}$ Department of Marine Ecology, National Environmental Research Institute, Frederiksborgvej 399, 4000 Roskilde, Denmark
}

\begin{abstract}
Effects of nutrient status and short-term, low-level exposure to the antifouling biocide copper pyrithione (CPT) on intact shallow-water sediment were studied in an outdoor experiment, focusing on basic ecosystem functions driven by microorganisms. These functions were trophic status (autotrophy/heterotrophy), direction of dissolved inorganic nitrogen (DIN) flux, and the ratio of algal $\mathrm{N}$ assimilation:denitrification, and were based on measurements of daily sediment-water oxygen and nitrogen fluxes and denitrification. Bacterial production and biomass of microphytobenthos, meiofauna, and bacteria were also measured. The recovery of the functions was studied for $38 \mathrm{~d}$. CPT exposure did not change basic ecosystem functions; the sediment remained autotrophic and a net sink of DIN, where microalgal N incorporation far exceeded denitrification. However, CPT affected individual $\mathrm{N}$-cycling variables (ammonium flux, denitrification), as well as community respiration and bacterial production, with the direction of the response depending on sediment nutrient status. Significant CPT effects were more frequent in the nutrient-enriched sediment. Direct toxic effects were followed by indirect food-web-mediated (top-down) effects, leading to different timing and direction of effects with different sediment nutrient status. Permutational multivariate analysis of variance showed that initial CPT effects on system functions in both nutrient regimes were followed by an oscillating recovery process, where effects remained longer in the nutrient-enriched sediment. While single CPT exposure events may not affect general metabolic functions (oxygen flux) - at least not in net autotrophic sediments - repeated CPT exposure of sediment microbiota may impact nitrogen cycling in shallow, eutrophied waters.
\end{abstract}

KEY WORDS: Sediment $\cdot$ Multiple stressors $\cdot$ Copper pyrithione $\cdot$ Nutrients $\cdot$ Oxygen $\cdot$ Nitrogen · Denitrification · Trophic state

\section{INTRODUCTION}

Shallow coastal areas are subject to simultaneous exposure from several anthropogenic stressors, such as pollutants and nutrients. Typically these environmental problems are examined separately - both in empirical studies and in modeling (Koelmans et al. 2001) but, in so doing, possible interactions between them are overlooked. Because it is realistic to expect such interactions to occur, it is relevant to investigate coastal ecosystems with respect to the effects of altered nutri- ent status on a system's sensitivity to pollutants (Interlandi 2002, Adams 2005). To date, the majority of aquatic studies on multiple stressors come from freshwater systems (Breitburg et al. 1999, Vinebrook et al. 2004 and references therein).

Understanding the ecological particulars of the coupling between nutrient status and pollutants is of high relevance for the sustainability of ecosystems, and, currently, we must also take into account the actions taken to decrease nutrient loading to combat marine eutrophication (e.g. Conley et al. 2002, Fear et al. 
2004). But the coupling between nutrients and pollutants is complex (Breitburg et al. 1999, Heugens et al. 2001, Fleeger et al. 2003), and several hypotheses can be suggested. Increased nutrient load may decrease the toxicant effect due to high nutrient status of organisms and dilution of the toxicant in increasing amounts of biomass (e.g. Koelmans et al. 2001 and references therein). But if the communities present in the eutrophied system have an inherently higher sensitivity, the effect of a toxicant could be increased, or increased effect could occur through a higher metabolic turnover rate. Similarly, low nutrient status could either increase the effect due to the additional stress of nutrient limitation, or decrease the effect due to lower metabolic activity.

We conducted an outdoor experiment using natural shallow-water sediment, in which the first goal was to consider the combined effects of nutrient status and toxicant exposure on the function and structure of marine, illuminated, shallow-water sediment systems. Due to high biological activity, such areas have an extensive capability to recycle, store, and remove nutrients, making them important buffer zones between land and sea (Nielsen et al. 2004). Because the water column in these areas is shallow, key ecosystem processes are related to microorganisms present in the surface sediment. These dense microbial communities not only drive central processes, such as decomposition and remineralization, but also the production of new organic material through the activity of benthic microalgae (BMA) (Underwood \& Kromkamp 1999). These algal communities also control the sedimentwater exchange of nutrients, directly by uptake and indirectly by oxygen production (for review see McGlathery et al. 2004), which in turn influences redox-sensitive processes, such as nitrification and denitrification (Risgaard-Petersen 2003). Although the effects of environmental changes and stressors on marine illuminated sediments have been investigated individually (Nilsson et al. 1991, Underwood \& Paterson 1993, Wulff et al. 2000, Piehler et al. 2003), studies on the sensitivity of these sediments to multiple impacts are still rare (Wulff et al. 2000, Laursen et al. 2002, Wiegner et al. 2003).

Our second goal was to consider the resilience of shallow-water sediment systems. Resilience is defined here as the time it takes for an affected system to become indistinguishable from a reference system after a temporary disturbance. Although theory and terminology dealing with different aspects of 'ecological stability', like the concept of resilience, have been extensively debated (Grimm \& Wissel 1997, Peterson et al. 1998), there are still few empirical studies on ecological stability from the marine environment. While the recovery rate of benthic macroscopic communities has been considered (Thrush \& Dayton 2002, Sheridan 2004), studies on the resilience of microscopic communities (and key functions driven by them) are rare (Underwood \& Paterson 1993, La Rosa et al. 2001, Wetzel et al. 2002). For example, how resilient are the basic ecosystem functions of the sediment, such as the degree of autotrophy and the capacity to retain and recycle nutrients?

Thus, our overall goal was to study whether, and how, the sensitivity and resilience of an ecosystem is linked to its nutrient status when exposed to a pollutant. The hypothesis was that nutrient status would affect both these properties of a shallow-water sediment system. Moreover, we hypothesized that sensitivity and resilience may depend on the trophic level of the organism. To maintain the indigenous complexity of the benthic system, we used natural sediment, including all its naturally occurring organisms and the processes governed directly or indirectly by them. The pollutant we used was copper pyrithione (CPT), which is a metal-pyrithione used as an anti-fouling biocide in the new generation of anti-fouling paints for boats. In Europe, CPT is only allowed in Finland, but the related compound, zinc pyrithione (ZPT) is widely used, and, when ZPT is released from the paint to the environment, it is transchelated into CPT (Grunnet \& Dahllöf 2005). Both ZPT and CPT degrade at high light intensities, but the degradation rate in low light intensities is negligible (Maraldo \& Dahllöf 2004a). CPT and ZPT have both been found to affect microbial diversity and microbial processes in sediments (e.g. $\mathrm{N}$ and $\mathrm{P}$ cycling) (Petersen et al. 2004), mainly through disruption of the cellular energy cycling (Dinning et al. 1998). In laboratory microcosm experiments, the lowest observed effect concentration (LOEC) for nutrient fluxes was between 0.1 and 1 nmol CPT $g^{-1}$ dry sediment, depending on the nutrient (Petersen et al. 2004). Also, phytoplankton and bacteria in the water column are affected at nano-molar concentrations of CPT (Maraldo \& Dahllöf 2004b).

Originally, we adopted a 'reductionistic' approach in our experiment by measuring abundance, diversity, and function of individual autotrophic and heterotrophic organism groups (microphytobenthos, bacteria, meiofauna) and by measuring nutrient and oxygen fluxes both during night and day. This resulted in a large number of individual variables $(20)$ to be considered. All these individual variables will be dealt with in detail in a paper by F. Larson et al. (unpubl.), which will describe a complex CPT response due to differences in the sensitivity of organism groups, their trophic level, different nutrient-status of the sediment, and a combination of direct and indirect effects. Our goal in the present paper was to extend findings from the level of individual components and processes to 
the ecosystem level. We have done this by focusing on a few ecosystem-level key properties, such as the trophic status (autotrophy vs. heterotrophy) and the capacity of the sediment to retain and remove nutrients, specifically nitrogen. The 3 main variables considered were net ecosystem metabolism (NEM; indicator of the trophic state), net flux of dissolved inorganic nitrogen (indicator of the sink/source function of the sediment), and the ratio between algal $\mathrm{N}$ assimilation and denitrification (indicator of the temporal $\mathrm{N}$ retention/N removal function). The specific questions asked were: What are the combined effects of nutrient status and low-level CPT exposure on: (1) the trophic status of an illuminated sediment system, (2) its capacity to function as a sink of nitrogen, and (3) the resilience of these system functions?

\section{MATERIALS AND METHODS}

General approach. The experiment was run in an outdoor continuous flow-through system using natural sediment. Intact sediment was collected with plastic cylinders that were used as flow-through aquaria in the experiment (48 cylinders in total). To create 2 sets of sediment systems that differed in nutrient status at the time of the toxicant exposure; half of the sediment aquaria were enriched with nitrogen and phosphorus for a period of $2 \mathrm{wk}$ (Fig. 1). After terminating the nutrient treatment, CPT was added during 4 consecutive nights to half of the un-enriched and half of the enriched aquaria (Fig. 1). This gave 4 treatments, with 12 cylinders in each: 1 low and 1 high nutrient treatment with no CPT addition $\left(\mathrm{Nu}_{\text {low }}\right.$ and $\left.\mathrm{Nu}_{\text {high }}\right)$ that served as controls and 1 low and 1 high nutrient treatment with CPT addition $\left(\mathrm{Nu}_{\text {low }} \mathrm{CPT}\right.$ and $\left.\mathrm{Nu}_{\text {high }} \mathrm{CPT}\right)$. Following the CPT addition, the system was monitored for a period of $38 \mathrm{~d}$. The duration and sampling intervals were set according to the response and resilience observed in previous single-stressor experiments on similar sediment systems focusing on the microbiota and their functions (Sundbäck et al. 1990, Nilsson et al. 1991, Sloth et al. 1996, Wulff et al. 1997). Functional variables included oxygen and nutrient fluxes, bacterial production, and denitrification; while structural variables included biomass of algae, meiofauna and macrofauna, abundance of bacteria, and sediment characteristics. Altogether, 13 functional and 6 structural variables (including some ratios) were assessed (Tables 1 \& 2).

Study site and sediment collection. Sediment was collected from a depth of 3 to $4 \mathrm{~m}$ in Munkeby Bay $\left(58^{\circ} 14^{\prime} \mathrm{N}, 11^{\circ} 32^{\prime} \mathrm{E}\right)$, in one of the sounds connecting Gullmar and Koljö Fjords on the microtidal (amplitude $30 \mathrm{~cm}$ ) Swedish Skagerrak coast. Sediment was collected using an Olausson box-corer $(300 \times 300 \mathrm{~mm})$, with care taken to minimize sediment disturbance. On board, the stainless steel core liner holding the sediment was detached, and excess overlying water was gently removed. A cylinder (ABS plastic, inner diameter $250 \mathrm{~mm}$, height $230 \mathrm{~mm}$ ) was pressed into the sediment, and when its rim was about $50 \mathrm{~mm}$ above the

Treatments:

No nutrients added

No CPT

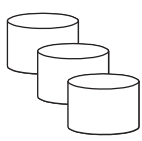

$\mathrm{Nu}_{\text {low }}$

12

\section{CPT added}

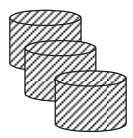

$\mathrm{Nu}_{\text {low }} \mathrm{CPT}$

12
Nutrients added

No CPT

CPT added


$\mathrm{Nu}_{\text {high }}$

$\mathrm{Nu}_{\text {high }} \mathrm{CPT}$

12

12

CPT addition



$\Delta$ Non-destructive sampling

- Destructive sampling

Fig. 1. Experimental design and sampling schedule 
sediment surface, the liner was lifted off and a plate of marine plywood was inserted from the side to function as the bottom of the cylinder. This cylinder could be used, without disturbing the sediment, in an experimental set-up on land. The sediment was silty sand, with an organic content of $10 \%$ (loss on ignition).

Experimental set-up. Forty-eight sediment cylinders were randomly placed in a greenhouse from which the glass wall panels had been removed. The sediment cylinders were provided with a flow-through of unfiltered seawater pumped from $4 \mathrm{~m}$ depth in the Gullmar Fjord into an elevated water container (300 l) from which the water was transported by gravity out to eight $1 \mathrm{~m}$ long horizontal tubes $(1000 \mathrm{~mm} \times 100 \mathrm{~mm})$ above the cylinders. From each tube, outlet tubes led to inlets placed $50 \mathrm{~mm}$ below the rim of each cylinder, giving a flow rate of $\sim 10 \mathrm{l} \mathrm{h}^{-1}$. The water left the cylinders by overflow. The inlets were regularly cleaned, as were the inner walls of the cylinders to avoid periphyton fouling. Filamentous green algae belonging to the genus Ulva (previously Enteromorpha) were removed weekly. Larger macrofauna, such as brittle stars and snails, were also removed. Salinity of incoming water varied between 26 and 29, and temperature, between 11 and $18^{\circ} \mathrm{C}$.

Nutrient loading. Half of the cylinders (24) were preexposed to continuous nutrient enrichment for $14 \mathrm{~d}$ using an in situ enrichment technique (Worm et al. 2000, Hillebrand \& Kahlert 2002) in which non-coated fertilizer pellets (Hydro Agri OptiCrop NPK 21-3-10), normally used in agriculture, were placed in mesh bags at the water inlet of each cylinder. The mesh bag contained initially $126 \mathrm{~g} \mathrm{~N} \mathrm{~m}^{-2}$ and $18 \mathrm{~g} \mathrm{P} \mathrm{m}^{-2}$, chosen according to Worm et al. (2000). The pellet bags were replaced 3 times during the enrichment period and removed after $14 \mathrm{~d}$, after which nutrient levels in the incoming water were equal to those in the near-surface water of Gullmar Fjord.

Toxicant. CPT (with dimethyl sulfoxide, DMSO, as solvent) was added to 12 low-nutrient cylinders (designated $\mathrm{Nu}_{\text {low }} \mathrm{CPT}$ ) and 12 high-nutrient cylinders $\left(\mathrm{Nu}_{\text {high }} \mathrm{CPT}\right)$. To ensure that the toxicant came rapidly into direct contact with the sediment surface, a slurry technique was used. A dilute sediment-toxicant slurry was added during 4 consecutive nights, giving a final concentration of $1 \mathrm{nmol} \mathrm{g}{ }^{-1}$ dry sediment. This concentration was chosen because it equals the LOEC found in laboratory microcosm experiments (Petersen et al. 2004). Before the slurry was added, the water flow was stopped and the water level lowered to the inlet level, to ensure that the toxicant reached the sediment. A sediment slurry with no CPT, but with DMSO, was added to the 24 other cylinders $\left(\mathrm{Nu}_{\text {low }}\right.$ and $\left.\mathrm{Nu}_{\text {high }}\right)$ to avoid a bias created by the slurry addition itself. This deposition was only a thin powdering $(<1 \mathrm{~mm})$ of the surface, most likely not affecting the algal community. Wulff et al. (1997) found that even after a deposition of $2.5 \mathrm{~mm}$ of new sediment, the microalgal community and oxygen profiles recovered quickly, mainly through upward migration of the algae.

Sampling. The day after the last CPT addition was Day 1 of the experiment. Samples were taken 7 times over 38 d from 9 September to 17 October 2002. Diel fluxes of oxygen and nutrients in the overlying water were measured on every sampling day, while destructive sediment sampling (organisms, sediment characteristics, bacterial production, and denitrification) was done every second week (on Days 1, 9, 24, and 38). After the destructive sampling, the cylinders were discarded. After the non-destructive sampling, the cylinders remained in the experiment until the next destructive sampling. At each sampling, notes on the color and texture of the sediment surface and the presence of filamentous green algae were made. The ambient temperature decreased from a maximum of $18^{\circ} \mathrm{C}$ in early September to $10.5^{\circ} \mathrm{C}$ degrees in October, during the night.

Oxygen and nutrient fluxes. Fluxes of oxygen, inorganic nutrients $\left[\mathrm{NH}_{4}{ }^{+}, \mathrm{NO}_{3}{ }^{-}+\mathrm{NO}_{2}{ }^{-}, \mathrm{PO}_{4}{ }^{3-}, \mathrm{Si}(\mathrm{OH})_{4}\right]$, and total $\mathrm{N}\left(\mathrm{T}_{\mathrm{N}}\right)$ were measured in 12 randomly chosen cylinders (3 replicate cylinders per treatment) at each sampling. The water flow was turned off, and the cylinders were closed by acrylic lids that were equipped with a Teflon-coated stirring bar (6 mm). Air bubbles below the lid were avoided. The bars were rotated by an external U-magnet driven by an electric motor. Oxygen concentrations were not allowed to change $>20 \%$ during incubation ( 1 to $2 \mathrm{~h}$ ), to avoid oxygen-induced changes in nutrient fluxes (Dalsgaard et al. 2000). Daytime sampling was done in early afternoon, and night-time sampling at midnight. Samples for time zero were taken from open cylinders (oxygen with a $20 \mathrm{ml}$ glass syringe, nutrients with a disposable $50 \mathrm{ml}$ syringe) and at the end of the incubation through a $5 \mathrm{~mm}$ opening in the lid. Oxygen concentrations were measured immediately after sampling using Winkler titrations. Nutrient samples were filtered $(0.45 \mu \mathrm{m}$ Sartorius syringe filters) and frozen immediately at $-20^{\circ} \mathrm{C}$. Inorganic nutrients and total nitrogen were analyzed by wet-chemistry methods using a Scalar Autoanalyzer (SCAN ${ }^{\text {PLUS }}$ ) at the National Environmental Research Institute (NERI) in Roskilde, Denmark. Dissolved organic nitrogen (DON) concentrations were calculated by subtracting dissolved inorganic nitrogen (DIN) from $\mathrm{T}_{\mathrm{N}}$. Hourly nutrient fluxes were converted to daily $(24 \mathrm{~h}$ ) rates by multiplying hourly light fluxes by the number of daylight hours and hourly night fluxes by the number of dark hours, and then adding these 2 numbers (light data from the Swedish Meteorological and Hydrological Institute). 
Primary productivity and community respiration. Oxygen flux in the light was used as a measure of net primary production (NPP). Gross primary production (GPP) was calculated by subtracting community respiration (CR) in the dark (a negative value) from NPP, assuming for practical reasons that respiration in the light equaled respiration in the dark. Daily values of NPP and GPP were calculated by multiplying flux rates per incubation time by a light factor calculated as a ratio between total daily irradiance and irradiance during the incubation period. NPP and GPP were converted to fixed carbon using a photosynthetic quotient (PQ) of 1.2 (for the motivation behind this quotient see Kirk [1994] and Glud et al. [2002]). Daily CR was calculated by multiplying hourly values by 24 , and converted to $C$ applying a respiratory quotient (RQ) of 1.2. The RQ may vary greatly, but 1.2 is close to the quotient found by Glud et al. (2002) for a BMA-dominated sediment. Net oxygen flux over a $24 \mathrm{~h}$ period (to assess the balance between autotrophy and heterotrophy) was calculated by adding NPP for the light period and CR during the dark hours. When converted to $\mathrm{C}$, this variable is equivalent to net ecosystem metabolism (NEM) (e.g. Wiegner et al. 2003), which is used here as an indicator of trophic status.

Benthic microalgal nitrogen assimilation. Nitrogen assimilation (A) by BMA was calculated from net daily NPP expressed as carbon (see above) and converted to $\mathrm{N}$ by assuming a $\mathrm{C}: \mathrm{N}$ molar ratio of 9 , the average found for natural BMA communities (Sundbäck \& Miles 2000, Hillebrand \& Kahlert 2002). Because assimilation rates are based on NPP $\left(A_{\mathrm{NPP}}\right)$, they provide conservative values of the BMA net $\mathrm{N}$ demand (Sundbäck \& McGlathery 2005).

Bacterial production. BP was estimated by ${ }^{14} \mathrm{C}$ leucine incorporation as described by Petersen et al. (2004). In short, 5 sub-samples (each $\sim 0.2 \mathrm{~g}$ of sediment) from each cylinder were incubated with $200 \mu \mathrm{l}$ of $5 \mu \mathrm{M}{ }^{14} \mathrm{C}$ leucine in the dark $\left(1 \mathrm{~h}, 15^{\circ} \mathrm{C}\right)$. The incubation was terminated by adding $20 \mu \mathrm{l}$ formalin, and the proteins were extracted in a buffer consisting of TE buffer and sodium lauryl sulfate (3\% SDS) using bead beating. The proteins were precipitated with $100 \%$ trichloroacetic acid $\left(\mathrm{CCl}_{3} \mathrm{COOH}\right)$ and skimmed milk to enhance precipitation. The samples were analyzed directly in Eppendorf tubes in a Beckman LS 1801 liquid scintillation counter. BP was calculated according to Simon \& Azam (1989) and converted to $\mathrm{mg} \mathrm{C} \mathrm{m} \mathrm{C}^{-2}$ using the dry weight (DW) of the sediment from porosity analyses.

Denitrification. Sediment denitrification (D) was measured using the isotope-pairing technique, which discriminates between denitrification supported by $\mathrm{NO}_{3}{ }^{-}$from the water column $\left(D_{\mathrm{w}}\right)$ and nitrification-coupled denitrification $\left(D_{\mathrm{n}}\right)$ in the sediment (Nielsen
1992). Here, only total daily denitrification rates $\left(D_{\text {tot }}=\right.$ $D_{\mathrm{w}}+D_{\mathrm{n}}$ ) are considered. $D$ was measured during other destructive samplings (4 occasions). Although light can affect denitrification rates (Risgaard-Petersen 2003), measurements were made only during the night for logistic reasons. The procedure for measuring denitrification is described by Dalsgaard et al. (2000). In short, Plexiglas tubes (internal diameter $35 \mathrm{~mm}, 250$ mm long, lids equipped with a magnetic stirring bar) were inserted into the sediment. ${ }^{15} \mathrm{NO}_{3}{ }^{-}\left(10 \mathrm{mmol} \mathrm{l} \mathrm{l}^{-1}\right.$ $\mathrm{Na}^{15} \mathrm{NO}_{3}, 99.6$ at.\%, Europa Scientific) was added to the headspace water (final concentration $\sim 30 \%$ of the $\mathrm{O}_{2}$ concentration). $\mathrm{NO}_{3}{ }^{-}$concentration was measured prior to the addition of ${ }^{15} \mathrm{NO}_{3}{ }^{-}$and when the cores were closed (after $\sim 0.5 \mathrm{~h}$ to allow the label to diffuse into the anoxic layer), in order to calculate the ${ }^{14} \mathrm{~N}:{ }^{15} \mathrm{~N}$ ratio in the ${ }^{15} \mathrm{NO}_{3}{ }^{-}$pool. For extraction of the $\mathrm{N}_{2}$ samples, $0.5 \mathrm{ml} \mathrm{ZnCl}_{2}\left(1 \mathrm{~g} \mathrm{ml}^{-1}\right)$ was added to the water phase, and gently but quickly mixed with the sediment. A slurry sample was transferred to a $12.5 \mathrm{ml}$ gas-tight vial. The isotopic ratio in $\mathrm{N}_{2}$ was analyzed by mass spectrometry at NERI, Silkeborg, Denmark. The denitrification rate was calculated according to the procedures and assumptions of Nielsen (1992). The daily denitrification was calculated by multiplying hourly values by 24 .

Assimilation:denitrification ratio. The balance between the temporal retention of $\mathrm{N}$ in benthic algal biomass and final $\mathrm{N}$ removal by denitrification was estimated by calculating the ratio between BMA assimilation $(A)$ and denitrification $(D)$ (A:D ratio) (Sundbäck \& Miles 2000).

Chlorophyll a. Five samples for chlorophyll a (chl a), used as a proxy for BMA biomass, were taken from each cylinder with a cut-off $2 \mathrm{ml}$ syringe (top $5 \mathrm{~mm}$ of the sediment). The samples were pooled, extracted with $90 \%$ acetone, sonicated, and stored cool and dark for $24 \mathrm{~h}$. Chl a concentration was measured spectrophotometrically according to Lorenzen (1967) and converted to algal biomass by applying a C:chl a ratio of 30 (de Jonge 1980, Sundbäck \& Miles 2000).

Total DNA content. DNA, used as a proxy for microbial biomass, was extracted by bead beating according to Petersen et al. (2004). In short, 5 sub-samples $(\sim 0.2 \mathrm{~g}$ sample ${ }^{-1}$ ) were taken from each cylinder and extracted with $1 \mathrm{ml}$ of extraction buffer consisting of $400 \mu \mathrm{l}$ of $6.25 \mathrm{M}$ ammonium acetate, $100 \mu \mathrm{l}$ of $1 \mathrm{M}$ Tris $(\mathrm{pH} 8)$, $40 \mu \mathrm{l}$ of $0.5 \mathrm{M}$ EDTA ( $\mathrm{pH}$ 8), and $460 \mu \mathrm{l}$ Milli-Q. To each tube, $80 \mu \mathrm{CTAB} / \mathrm{NaCl}$ and $15 \mu$ fluorescent $\operatorname{Extr}_{\mathrm{IS}}$ $\left(\sim 25 \mathrm{ng} \mathrm{ll}^{-1}\right)$ were added together with $200 \mu \mathrm{l}$ of silica beads (Biospec Products), $0.015 \mathrm{~g}$ of acid-washed PVPP, and $300 \mu$ of chloroform:isoamylalcohol (24:1) (Lab Scan and Merck). The samples were beaten (30 s at $5.5 \mathrm{~m} \mathrm{~s}^{-1}$ ) in a BIO-101 bead beater (Savant), followed by centrifugation of the supernatants for $20 \mathrm{~min}$ 
at $15000 \times g$ to precipitate proteins. The new supernatants were transferred to $2 \mathrm{ml}$ Eppendorf tubes, $100 \mu \mathrm{l}$ of $3 \mathrm{M} \mathrm{NaAc}(0.1 \times$ volume $)$ was added, and the tubes were topped up with isopropanol (Sigma) (minimum $0.6 \times$ volume), vortexed, and precipitated overnight $\left(4^{\circ} \mathrm{C}\right)$. The samples were centrifuged (30 min, $15000 \times g, 15^{\circ} \mathrm{C}$ ), and the pellets were washed with ice-cold $75 \%$ ethanol, and then the DNA was dissolved in $100 \mu \mathrm{l}$ TE. The total amount of DNA was quantified with PicoGreen ${ }^{\circledR}$ (Molecular Probes) on a fluorescence spectrophotometer (Fluorstar, BMG).

Bacterial abundance. Five sub-samples ( 0.2 g sample $^{-1}$ ) were taken from each cylinder, and DNA was extracted by bead beating according to Petersen et al. (2004). During DNA extraction internal standards were used to compensate for experimental variability (Petersen \& Dahllöf 2005). The number of bacterial 16S rRNA gene copies (Eubacteria) was used as a proxy for bacterial abundance using real-time quantitative polymerase chain reaction according to Skovhus et al. (2004).

Meiofauna. Three $5 \mathrm{~mm}$ deep samples were taken (cut-off $20 \mathrm{ml}$ syringe) from each cylinder, pooled, and preserved with formalin containing Bengal-Rose. The fauna were collected on a $100 \mu \mathrm{m}$ mesh and counted in a dissection microscope, allocating animals to major taxonomic groups. Biomass of these groups was estimated by applying values that are valid for the Gullmar area (Widbom 1984).

Sediment characteristics. Water content of the top $5 \mathrm{~mm}$ was estimated gravimetrically by drying sediment to constant weight at $60^{\circ} \mathrm{C}$. Solid-phase total $\mathrm{C}$ and $\mathrm{N}$ were determined on dried samples (top $5 \mathrm{~mm}$ ) using a Carlo Erba CHN elemental analyzer. Before analysis, samples for organic $\mathrm{C}$ content were treated with $\mathrm{HCl}$ to remove carbonates. Loss on ignition was measured on dried sediment after $6 \mathrm{~h}$ at $550^{\circ} \mathrm{C}$.

Statistical analyses. Outliers in the data set were removed when they were caused by experimental errors, such as leaking cylinders. Differences between treatments were analyzed by 2-way analysis of variance (ANOVA), with Time and Treatment as fixed factors. Homogeneity of variances was tested by Cochran's $C$-test, and heterogeneous data were transformed according to Underwood (1997). When there was a significant interaction between factors, pair-wise comparisons of the means were made using StudentNewman-Keuls test (SNK). One-way ANOVA was occasionally used to check differences for individual days. Pearson correlation analysis was used to look for correlations between variables. Whenever the word significant is used in the text, it refers to $p<0.05$.

Two-way permutational multivariate analysis of variance (PERMANOVA) (Anderson 2001, McArdle \& Anderson 2001), with Treatment and Day as fixed factors, was used to analyze the integrated system function and its recovery. Permutation implies random re-assignment of the observations to the treatment groups under each variable, with subsequent recalculation of the $F$-statistics. This is repeated many times to create a distribution of $F$-values, which then is used for comparison with the $F$-value from the original data set instead of tabulated values. Two separate analyses were run, one using the $7 \mathrm{~d}$ data set, including daily $\mathrm{NPP}, \mathrm{CR}$, and $\mathrm{NH}_{4}$ and $\mathrm{NO}_{3}$ fluxes, and a second analysis using the $4 \mathrm{~d}$ data set, including daily $\mathrm{NPP}, \mathrm{CR}, \mathrm{NH}_{4}, \mathrm{NO}_{3}$ and DON fluxes, $\mathrm{BP}$, and denitrification. The raw data were not transformed, but were standardized to $z$-scores (normalized). The analysis was based on Euclidean distances. A total of 9999 unrestricted permutations of raw data were used. To test when the CPT treatments were inseparable from the treatments without CPT addition, a posteriori pair-wise comparisons were done with the factor Treatment under each level of the factor Day. After the PERMANOVA, a test with permutational multivariate dispersion (PERMDISP) was run to find differences in within-group dispersion based on the sample distance to the group centroid. Finally, principal co-ordinate analysis (PCO) was calculated and plotted. The multivariate analysis was run using the computer programs PERMANOVA v. 1.6 (Anderson 2001, 2005, McArdle \& Anderson 2001), PERMDISP (Anderson 2004), and PCO3 (Anderson 2003).

\section{RESULTS}

\section{Ecosystem key functions}

To assess the overall ecosystem-level response to CPT under the 2 nutrient conditions, we will focus on variables that describe metabolic rates and nitrogen cycling, i.e. daily NPP, GPP, CR, NEM, daily sediment-water nitrogen flux, denitrification, and algal $\mathrm{N}$ assimilation. However, to give an overall general picture of the results, the responses of all measured variables are listed in Tables $1 \& 2$. Graphs of bacterial production and biomass of organism groups are also included to aid interpretation of the results.

\section{Nutrient status of the sediment}

A different nutrient status in the $\mathrm{Nu}_{\text {high }}$ treatment was achieved after the $14 \mathrm{~d}$ nutrient treatment. On Day 1 , the activity of the $\mathrm{Nu}_{\text {high }}$ sediment was higher than for $\mathrm{Nu}_{\text {low }}$, as shown by significantly higher rates of GPP, CR, nitrate and DIN uptake, and denitrifica- 
Table 1. Effects of $14 \mathrm{~d}$ nutrient enrichment on functional and structural variables in coastal, shallow-water sediment analyzed by 2-way ANOVA. Factors used were Day (D) and nutrient treatment (T). T: single main-factor effect of nutrient treatment; $\mathrm{D} \times \mathrm{T}$ : significant interaction between the 2 factors; 'Significant on day(s)': the day or days on which the effect was significant as analyzed using Student-Newman-Keuls test or 1-way ANOVA [denoted by*]; $\mathrm{p}<0.05$ and, when in parentheses, $0.05<\mathrm{p}<0.1$.

\begin{tabular}{|c|c|c|c|}
\hline & $\begin{array}{l}\text { Significant } \\
\text { factor }\end{array}$ & $\mathrm{p}$ & $\begin{array}{l}\text { Significant } \\
\text { on day }\end{array}$ \\
\hline \multicolumn{4}{|l|}{ Functional variables } \\
\hline \multicolumn{4}{|l|}{ NEM (net ecosystem metabolism) } \\
\hline GPP (gross primary production) & $\mathrm{T}$ & 0.026 & \\
\hline \multicolumn{4}{|l|}{ NPP (net primary production) } \\
\hline CR (community respiration) & $\mathrm{D} \times \mathrm{T}$ & 0.024 & 1 \\
\hline \multicolumn{4}{|l|}{ BP (bacterial production) } \\
\hline$D_{\text {tot }}$ (total sediment denitrification) & $\mathrm{D} \times \mathrm{T}$ & 0.033 & 1 \\
\hline $\begin{array}{l}A_{\mathrm{NPP}}: D \text { (assimilation rates based } \\
\quad \text { on NPP/denitrification) }\end{array}$ & $\mathrm{D} \times \mathrm{T}$ & 0.021 & $1,(38)$ \\
\hline $\mathrm{NO}_{3}^{-}$flux & & 0.017 & $1^{*}$ \\
\hline \multicolumn{4}{|l|}{$\mathrm{NH}_{4}^{+}$flux } \\
\hline DIN (dissolved inorganic nitrogen) flux & & 0.013 & $1^{*}$ \\
\hline \multicolumn{4}{|l|}{ DON (dissolved organic nitrogen) flux } \\
\hline $\mathrm{PO}_{4}{ }^{3-}$ flux & $\mathrm{D} \times \mathrm{T}$ & 0.021 & $1,3,16,24$ \\
\hline $\mathrm{Si}(\mathrm{OH})_{4}$ flux & $(\mathrm{D} \times \mathrm{T})$ & $(0.056)$ & 1 \\
\hline \multicolumn{4}{|l|}{ Structural variables } \\
\hline Total DNA & $\mathrm{T}$ & 0.013 & \\
\hline Algal biomass & $\mathrm{T}$ & 0.006 & \\
\hline Bacterial biomass & $\mathrm{T}$ & 0.010 & \\
\hline Meiofaunal biomass & $\mathrm{T}$ & 0.015 & \\
\hline \multicolumn{4}{|l|}{ POC (particulate organic carbon) } \\
\hline PON (particulate organic nitrogen) & & & \\
\hline
\end{tabular}

ods used to measure them. In both treatments, the sediment system was initially autotrophic, and remained so through most of the experiment (Fig. 2c).

The multivariate analysis (PERMANOVA) of the functional variables (oxygen and nitrogen fluxes, denitrification and bacterial production; see 'Materials and methods-Statistical analyses') showed that the integrated function (i.e. the 'net sum' of the functions) in the $\mathrm{Nu}_{\text {low }}$ and $\mathrm{Nu}_{\text {high }}$ sediments was significantly different on Day $1(\mathrm{p}=$ 0.015 and $\mathrm{p}=0.007$ for the 7 and $4 \mathrm{~d}$ data sets, respectively; Figs. $6 \& 7$ ).

\section{CPT effects on the low-nutrient system}

Initial effects

Initial effects are defined here as those seen on the first day (Day 1) after the 4-night CPT addition (Table 2). But these initial effects result from exposure over $3.5 \mathrm{~d}$, and are therefore probably a mixture of direct and indirect effects of CPT. On Day 1, there was a significant effect of the CPT addition on CR (Fig. 2b) and tion (Table 1, Figs. 2, 3 \& 4). Also NEM, NPP and DON effluxes in enriched cylinders were higher on Day 1 (Figs. 2 \& 3). Moreover, sediment in $\mathrm{Nu}_{\text {high }}$ had significantly higher total DNA content and higher algal and bacterial biomass, while meiofaunal biomass was significantly lower (Table 1, Fig. 5). The fact that daily DIN uptake was significantly correlated with both GPP ( $\mathrm{r}=0.70, \mathrm{p}=0.01)$ and NPP ( $\mathrm{r}=0.73$, $\mathrm{p}=0.01$ ) in the $\mathrm{Nu}_{\text {low }}$, but not in the $\mathrm{Nu}_{\text {high }}$ treatment, showed that our sediment system was initially nitrogen limited. No such significant correlation existed for phosphate or silica.

Particularly in the $\mathrm{Nu}_{\text {high }}$ treatments, well-developed diatom mats were visible as a brown bubbly surface layer on the sediment. Estimates of BMA carbon (1 to $3 \mathrm{~g} \mathrm{C} \mathrm{m}^{-2}$ ) exceeded meiofaunal biomass ( $\sim 2$ to $0.42 \mathrm{~g} \mathrm{C} \mathrm{m}^{-2}$ ) by an order of magnitude in both nutrient treatments (Fig. 5). Roughly $6 \%\left(\mathrm{Nu}_{\text {low }}\right)$ and $25 \%$ $\left(\mathrm{Nu}_{\text {high }}\right)$ of the particulate organic carbon (POC) in the top $5 \mathrm{~mm}$ sediment originated from benthic microalgae, while meiofauna accounted for 2 and $1 \%$ of the POC, respectively. Bacterial and algal biomass cannot be directly compared because of the different meth- denitrification (Fig. 4b) - both of these increased. Consequently, the $A: D$ ratio decreased significantly (Fig. 4c). The increased CR did not result in a change of the trophic state (Fig. 2c), and there was no change in nitrogen fluxes or biomass of organisms (Table 2 , Figs. 3 \& 5).

\section{Effects throughout the experimental period}

The CPT effect on CR remained during the experiment, although the direction of the response (increase or decrease of the flux rate) varied with time (Table 2 , Fig. 2b). There was, however, no change of the trophic status, and the system remained net autotrophic (Fig. 2c). Although CPT appeared to decrease (although not significantly) denitrification on Day 9 (Fig. 4b), daily $\mathrm{N}$ fluxes remained unaffected and the sediment functioned as a net sink of DIN (Fig. 3c). CPT had increased the total DNA content and bacterial abundance by Day 9, while algal and meiofaunal biomass were not significantly affected (Table 2, Fig. 5). 
Table 2. Effects of copper pyrithione (CPT) addition in coastal, shallow-water sediment, without and with pre-treatment by nutrient addition analyzed by 2-way ANOVA. Factors used were Day (D) and CPT treatment (T) (T: single main-factor effect of CPT treatment; D $\times$ T: significant interaction between the 2 factors; 'Significant on day(s)': day of the experiment the effect was significant as analyzed using Student-Newman-Keuls test or 1 -way ANOVA [denoted by*]; $\mathrm{p}<0.05$ and, when in parentheses, $0.05<\mathrm{p}<0.1$ ). For variable definitions, see Table 1

\begin{tabular}{|c|c|c|c|c|c|c|}
\hline & \multicolumn{3}{|c|}{$\longrightarrow$ No nutrient addition -} & \multirow[b]{2}{*}{$\begin{array}{l}\text { Significant } \\
\text { factor }\end{array}$} & \multirow{2}{*}{$\begin{array}{c}\text { Nutrient addition } \\
\mathrm{p}\end{array}$} & \multirow{2}{*}{ n $\begin{array}{c}\text { Significant } \\
\text { on day }\end{array}$} \\
\hline & $\begin{array}{l}\text { Significant } \\
\text { factor }\end{array}$ & $\mathrm{p}$ & $\begin{array}{l}\text { Significant } \\
\text { on day(s) }\end{array}$ & & & \\
\hline \multicolumn{7}{|l|}{ Functional variables } \\
\hline $\begin{array}{l}\text { NEM } \\
\text { NEM, Days } 9-24\end{array}$ & & \multicolumn{5}{|c|}{ NEM } \\
\hline \multicolumn{7}{|l|}{ GPP } \\
\hline NPP & & & & & $(0.066)$ & $\left(6^{*}\right)$ \\
\hline NPP, Days 9-24 & & & & $\mathrm{T}$ & 0.044 & \\
\hline CR & $\mathrm{D} \times \mathrm{T}$ & 0.003 & $1,3,9,24$ & $\mathrm{D} \times \mathrm{T}$ & 0.022 & (1) 24,31 \\
\hline $\mathrm{BP}$ & & & & $\mathrm{D} \times \mathrm{T}$ & 0.047 & 9,24 \\
\hline$D_{\text {tot }}$ & $\mathrm{D} \times \mathrm{T}$ & $(0.054)$ & $1^{*}$ & $\mathrm{~T}$ & 0.004 & \\
\hline$A: D_{\text {tot }}$ & $\mathrm{D} \times \mathrm{T}$ & 0.041 & 1 & $\mathrm{~T}$ & 0.002 & \\
\hline \multicolumn{7}{|l|}{$\mathrm{NO}_{3}^{-}$flux } \\
\hline $\mathrm{NH}_{4}{ }^{+}$flux & & & & $\mathrm{D} \times \mathrm{T}$ & 0.001 & $1,3,16,24,38$ \\
\hline DIN & & & & $\mathrm{T}$ & 0.008 & $1^{*}$ \\
\hline DON flux & & & & $\mathrm{D} \times \mathrm{T}$ & 0.030 & 1,38 \\
\hline $\mathrm{PO}_{4}^{-3}$ flux & & & & $\mathrm{D} \times \mathrm{T}$ & 0.009 & 3,9 \\
\hline $\mathrm{Si}(\mathrm{OH})_{4}$ flux & $\mathrm{D} \times \mathrm{T}$ & $(0.054)$ & 1,3 & $\mathrm{D} \times \mathrm{T}$ & 0.047 & $9,16,24$ \\
\hline \multicolumn{7}{|l|}{ Structural variables } \\
\hline Total DNA & $\mathrm{T}$ & 0.017 & $9^{*}$ & $\mathrm{~T}$ & 0.026 & \\
\hline Algal biomass & & & & $\mathrm{T}$ & 0.037 & $24^{*}$ \\
\hline Bacterial biomass & $\mathrm{T}$ & 0.017 & $9^{*}$ & & & \\
\hline Meiofaunal biomass & & $(0.097)$ & $\left(38^{*}\right)$ & & $(0.079)$ & $\left(24^{*}\right)$ \\
\hline \multicolumn{7}{|l|}{ POC } \\
\hline PON & $\mathrm{T}$ & 0.002 & $24^{*}$ & & & \\
\hline
\end{tabular}

\section{Effects of CPT on the high-nutrient system}

\author{
Initial effects
}

The most obvious difference in initial CPT effects between the $\mathrm{Nu}_{\text {low }}$ and $\mathrm{Nu}_{\text {high }}$ treatments was that the $\mathrm{N}$ cycle was more clearly affected in the $\mathrm{Nu}_{\text {high }}$ sediment. On Day 1, CPT had significantly reduced both DIN uptake and DON efflux and turned ammonium flux from uptake to efflux (Table 2, Fig. 3). In contrast to the $\mathrm{Nu}_{\text {low }}$ treatment, denitrification decreased in the $\mathrm{Nu}_{\text {high }}$ sediment, which led to an increase in the $A: D$ ratio (Fig. 4b,c). CPT decreased CR $(\mathrm{p}=0.08)$ on Day 1 (Table 2, Fig. 2b), but, again, no change in the trophic status occurred (Fig. 2c). No effect could be seen on the individual structural variables, such as biomass of organisms (Table 2, Fig. 5).

\section{Effects throughout the experimental period}

Significant effects of CPT were found on more functional variables and on more occasions in the $\mathrm{Nu}_{\text {high }}$ sediment than in the $\mathrm{Nu}_{\text {low }}$ sediment (Table 2). Moreover, in $\mathrm{Nu}_{\text {high }}$ treatment these effects occurred later in the experiment, resulting in a different temporal pattern rather than in consistently higher or lower rates. CPT affected CR later in the experiment (Fig. 2b), but, again, no general change in the trophic status occurred (Fig. 2c). CPT increased algal activity as shown by higher NPP and NEM during the period Day 9 to 24 (for GPP this trend was not statistically significant; Fig. 2). Also bacterial production increased during the same period (Table 2, Fig. 2e). Again, in contrast to the $\mathrm{Nu}_{\text {low }}$ system, $\mathrm{N}$ cycling was significantly affected also later in the experiment (Fig. 3); $\mathrm{NH}_{4}{ }^{+}$flux changed from efflux to uptake in the middle of the experiment (Fig. 3a). A similar change was not seen for $\mathrm{NO}_{3}{ }^{-}$, and DIN flux was significantly lower only on Day 3. Rates of DON efflux ( 0.5 to $5 \mathrm{mmol} \mathrm{m} \mathrm{m}^{-2} \mathrm{~d}^{-1}$ ) were similar to those of DIN influx ( 0.5 to $3 \mathrm{mmol} \mathrm{m}^{-2} \mathrm{~d}^{-1}$ ), and were significantly affected (increase) by CPT only on the final day (Fig. 3c,d). Denitrification showed an overall significant decrease (main factor effect; Table 2, Fig. 4b). This, together with increased algal assimilation during the period Day 9 to 24 (Fig. 4a), led to an overall significantly increased $A: D$ ratio (Table 2, Fig. 4c). Among structural variables, only total DNA was overall significantly affected by CPT, while microalgal carbon was affected only on Day 24 (Table 2, Fig. 5). 
Low nutrient High nutrient

Gross primary production (GPP)
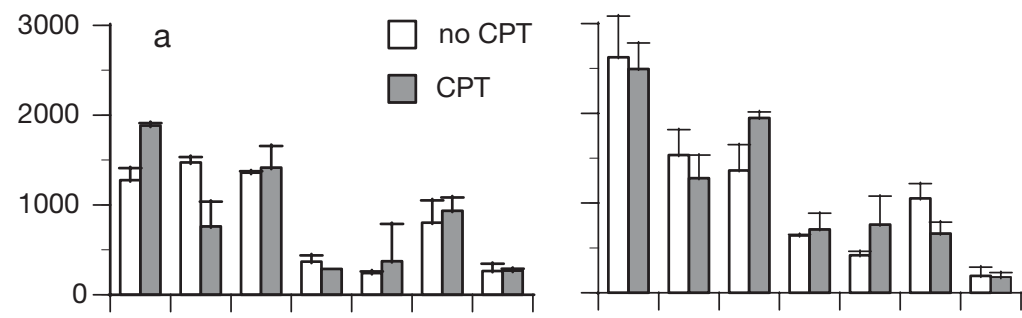

b
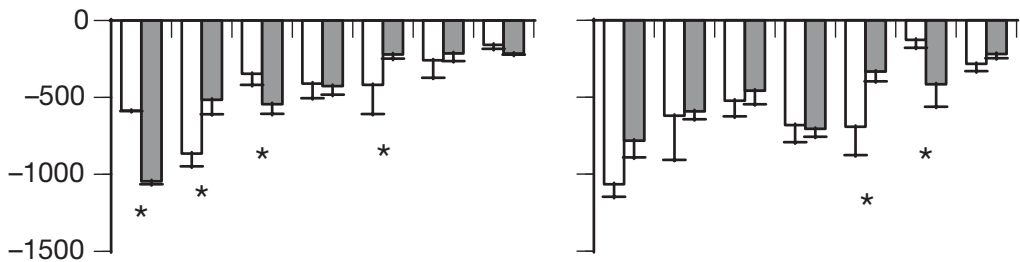

Net ecosystem metabolism (NEM)
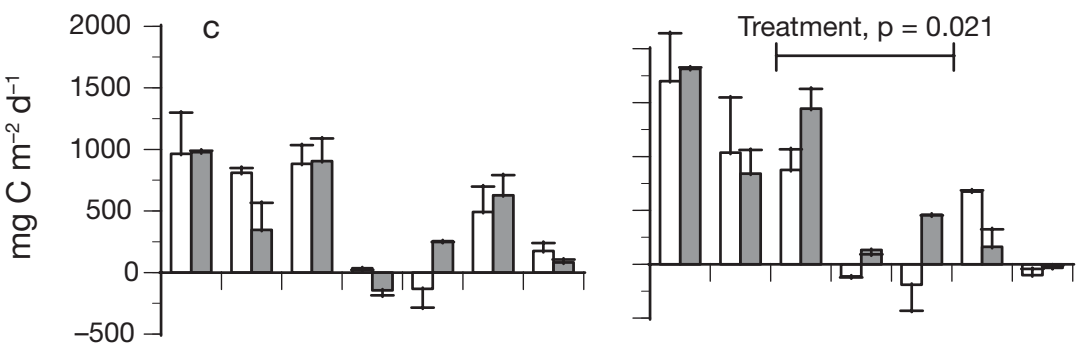

Net primary production (NPP)
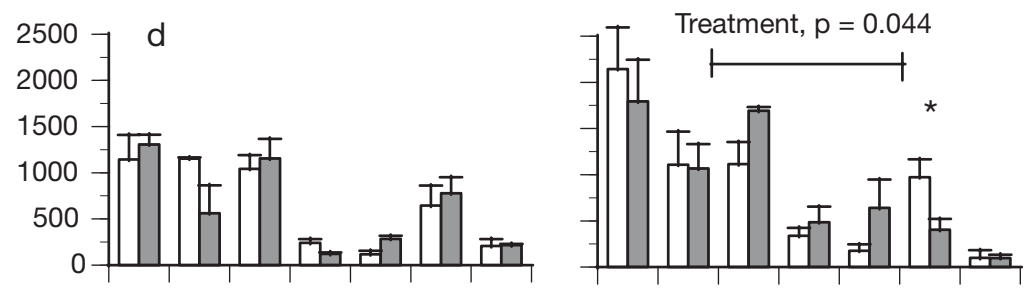

Bacterial production (BP)


Fig. 2. Daily (a) gross primary production, (b) community respiration, (c) net ecosystem metabolism, (d) net primary production and (e) bacterial production in $\mathrm{Nu}_{\text {low }}$ (left panels) and $\mathrm{Nu}_{\text {high }}$ treatments (right panels), with and without addition of copper pyrithione (CPT). Shown are means + SE ( $n=2$ to 3). Treatment: significant main treatment effect of CPT (2-way ANOVA); ${ }^{*}$ : significant CPT effect on an individual day (SNK or 1-way ANOVA, $\mathrm{p}<0.05$ )

\section{Integrated system response and resilience}

The multivariate analysis (PERMANOVA) of both the $7 \mathrm{~d}$ data including 4 variables (NPP, $\mathrm{CR}, \mathrm{NH}_{4}$ and $\mathrm{NO}_{3}$ fluxes) and the $4 \mathrm{~d}$ data including 7 variables (DON flux, denitrification and bacterial production were added) gave essentially the same picture of the response and recovery of the integrated system function (Figs. $6 \& 7$ ). The response appeared to oscillate and was different for low- and high-nutrient systems. On Day 1, both the systems were affected by CPT as shown by the separation of the CPT treatments into distinct, significantly different clusters in the PCO graph (Table 3, Figs. 6 \& 7). However, after this the significant CPT effect disappeared in the $\mathrm{Nu}_{\text {low }}$ sediment. First the dispersion of samples increased, but from Day 24 onwards all the $\mathrm{Nu}_{\text {low }}$ samples were grouped tightly together, suggesting recovery by Day 24 (Fig. 6). Also the $\mathrm{Nu}_{\text {high }}$ samples were dispersed for a period after the initial effects, but a significant CPT effect re-occurred on Day 16 and remained on Day 24 (Figs. 6 \& 7). On Day 38, no distinct groups were found, suggesting recovery, since the earlier CPT-affected samples were now indistinguishable from the no-CPT treatments. However, when comparing the temporal evolution described by the PERMANOVA with the evolution of individual variables, it can be seen that $\mathrm{NH}_{4}$ and DON fluxes and denitrification were still significantly different on Day 38 in the nutrient-enriched sediment (Table 2, Fig. 3).

\section{DISCUSSION}

The choice of using 'undisturbed' sediment implied a deliberate trade-off between retaining the initial complexity and heterogeneity of a natural sediment system and gaining more clearcut results from simplified (e.g. sieved and homogenized) sediment systems. However, despite the inherent heterogeneity of our natural sediment sys- 




Fig. 3. Daily flux of (a) $\mathrm{NH}_{4}{ }^{+}$, (b) $\mathrm{NO}_{3}{ }^{-}+\mathrm{NO}_{2}{ }^{-}$, (c) dissolved inorganic (DIN) and organic nitrogen (DON) in $\mathrm{Nu}_{\text {low }}$ (left panels) and $\mathrm{Nu}_{\text {high }}$ treatments (right panels), with and without addition of copper pyrithione (CPT). Shown are means + $\mathrm{SE}(\mathrm{n}=2$ to 3$){ }^{*}$ : significant $(\mathrm{p}<0.05)$ effect of CPT for an individual day (SNK or 1 -way ANOVA, $\mathrm{p}<0.05$ )

tems, significant effects of short-term, low-level CPT additions were evident on both individual and integrated ecosystem variables, in both the $\mathrm{Nu}_{\text {low }}$ and the $\mathrm{Nu}_{\text {high }}$ treatments (Tables 2 \& 3). The following general response patterns emerged. (1) CPT effects depended on nutrient status; a higher number of effects were measurable in the nutrient-richer sediment (Table 2); also the direction of the initial effects differed with nutrient status. (2) Although primary production and community respiration were affected by $\mathrm{CPT}$, no overall change in the trophic state occurred. (3) CPT did not change the role of the sediment as a net sink of total
DIN either, despite the fact that some individual processes involved in $\mathrm{N}$ turnover (ammonium flux, denitrification) were significantly affected. (4) Initial ('direct') CPT effects appeared to be followed by a sequence of indirect food-web-mediated effects, leading to different timing and direction of effects in sediments with different nutrient status. (5) The recovery after the initial CPT exposure was an oscillating process and appeared to be slower in the nutrient-enriched system, making it difficult to determine if final recovery occurred during the experiment.

\section{CPT effects on basic ecosystem functions}

Trophic state

Individual autotrophic and heterotrophic processes were affected, but the CPT additions did not result in an overall change of the NEM or trophic status of the ecosystem. The fact that heterotrophic processes (aerobic respiration and denitrification) were affected more than primary production, suggests that autotrophs were less sensitive to CPT than heterotrophs. A possible explanation may be that, as heterotrophy is tightly coupled to organic matter produced by autotrophs, even partial toxicant effects on primary producers may be reflected more strongly in the heterotrophic processes. A highly significant correlation between BP and GPP in our study ( $\mathrm{r}=0.74, \mathrm{p}=0.001$ ) supports the presence of this coupling.

The fact that primary production (and NEM) was not negatively affected by CPT suggests that even if the microalgae were initially affected, they must have rapidly recovered, since we could not see any significant effect on Day 1 . This is in accord with the results from previous experiments using single stressors (e.g. biocides, oxygen deficiency, and sedimentation) on benthic microalgae (Underwood \& Paterson 1993, Wulff et al. 1997, F. Larson unpubl. data, F. Larson \& K. Sundbäck unpubl. data); in those experiments primary production recovered within days. However, Piehler et al. (2003) found that, although the primary production of diesel-fuel-exposed benthic microalgae recovered within $5 \mathrm{~d}$, the photo- 
Low nutrient

High nutrient

Algal assimilation of $\mathrm{N}(A)$

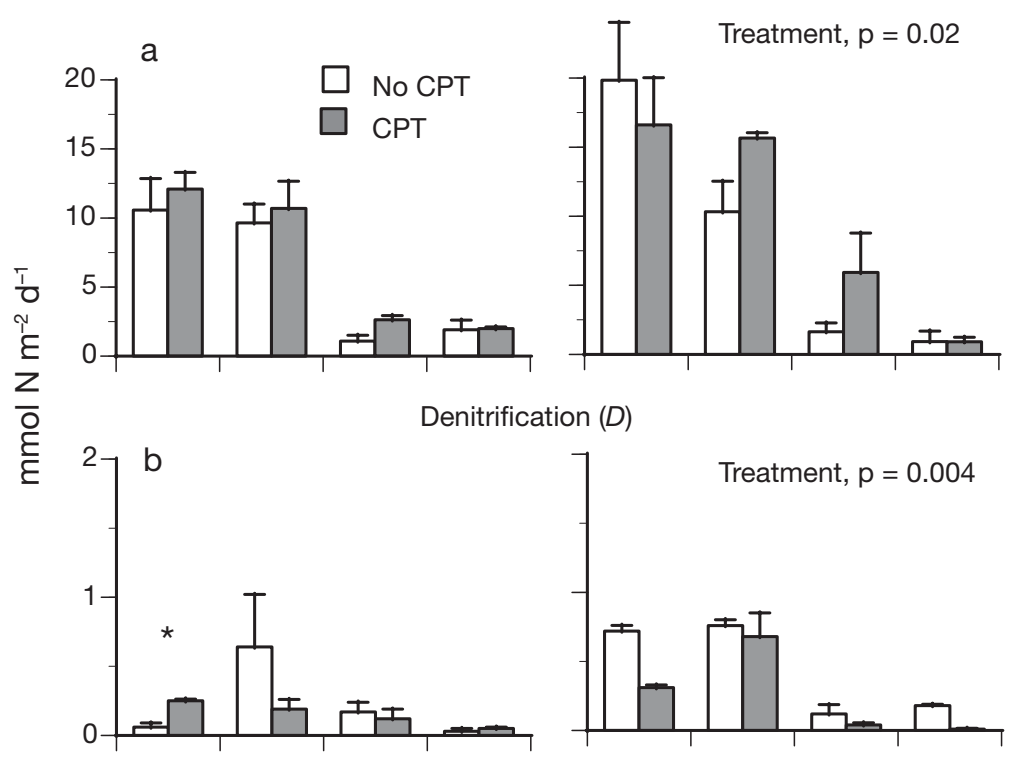

C Ratio algal $\mathrm{N}$-assimilation:denitrification $(A: D)$

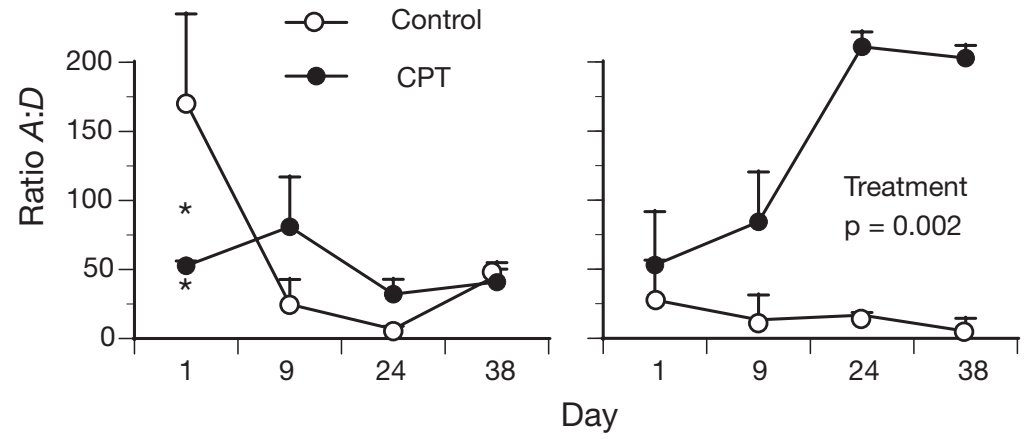

Fig. 4. (a) Daily microalgal nitrogen assimilation calculated from net primary production, (b) measured daily denitrification, and (c) the assimilation/denitrification ratio in $\mathrm{Nu}_{\text {low }}$ (left panels) and $\mathrm{Nu}_{\text {high }}$ treatments (right panels), with and without addition of copper pyrithione (CPT). Shown are means $+\mathrm{SE}(\mathrm{n}=2$ or 3$)$. For assimilation, a C/N ratio of 9 has been used (see 'Materials and methods Benthic microalgal nitrogen assimilation' for justification. Treatment: significant main treatment effect of CPT $(2$-way ANOVA $) i^{*}$ : significant $(\mathrm{p}<0.05)$ effect of $\mathrm{CPT}$ for an individual day (SNK or 1 -way ANOVA, $\mathrm{p}<0.05$ )

physiology (studied by $P-I$ curves) remained negatively affected, hinting that longer effects on the photosynthetic apparatus may actually remain.

Our sediment systems were initially highly autotrophic. Stable net autotrophy of sediments may function as a buffering mechanism against environmental changes (de Wit et al. 2001 and references therein) by maintaining a positive oxygen balance and net nutrient assimilation. The observation that CPT effects were larger on night fluxes of nutrients than on day-time fluxes (F. Larson et al. unpubl.), also supports the idea that photoautotrophic processes are important for sys- tem stability. The fact that CR (night oxygen flux) was more strongly affected than primary production, further suggests that, with increasing heterotrophy, the system may become more vulnerable to the toxicant. Hence, effects of CPT could be expected to be higher in more silty or deeper sediments.

\section{Direction of nitrogen flux}

Few studies have considered the effect of contaminants on benthic nutrient cycling in aquatic environments (for references see Fleeger et al. 2003). In our study, one of the clearest combined nutrient-CPT effects was seen in nitrogen cycling; $\mathrm{NH}_{4}{ }^{+}$efflux was exceeded by influx after CPT addition in the $\mathrm{Nu}_{\text {high }}$ treatments (Fig. 3a). But the main direction of DIN flux remained unaffected due to unchanged rates of $\mathrm{NO}_{3}{ }^{-}$fluxes, rates which exceeded those of $\mathrm{NH}_{4}^{+}$fluxes. The effect on $\mathrm{NH}_{4}{ }^{+}$flux may be a combination of higher $\mathrm{N}$ demand by BMA (indicated by higher primary production, higher algal biomass, and higher silicate uptake; F. Larson et al. unpubl.), together with decreased infaunal activity and decreased bacterial $\mathrm{NH}_{4}{ }^{+}$production. We suggest that the effects on ammonium fluxes were mainly due to higher $\mathrm{N}$ uptake by BMA. The calculated $\mathrm{N}$ demand by BMA (1 to $20 \mathrm{mmol}$ $\mathrm{N} \mathrm{m}^{-2} \mathrm{~d}^{-1}$; Fig. 4a) far exceeded measured DIN uptake by the sediment ( $\sim 0.5$ to $3 \mathrm{mmol} \mathrm{N} \mathrm{m}^{-2} \mathrm{~d}^{-1}$; Fig. 3c), suggesting that the pore-water pool of $\mathrm{N}$ must have been an important $\mathrm{N}$ source to meet the $\mathrm{N}$ demand of the microalgae.

Balance between nitrogen assimilation and removal

Denitrification was one of the few variables that was consistently affected by the nutrient-CPT combination. The decreased denitrification alone could not explain the consistent significant increase in the $A: D$ ratio, and the increase was probably due to a combined increase in $\mathrm{N}$ incorporation by BMA and decreased denitrification. The decreased denitrification could be due either to increased competition for 

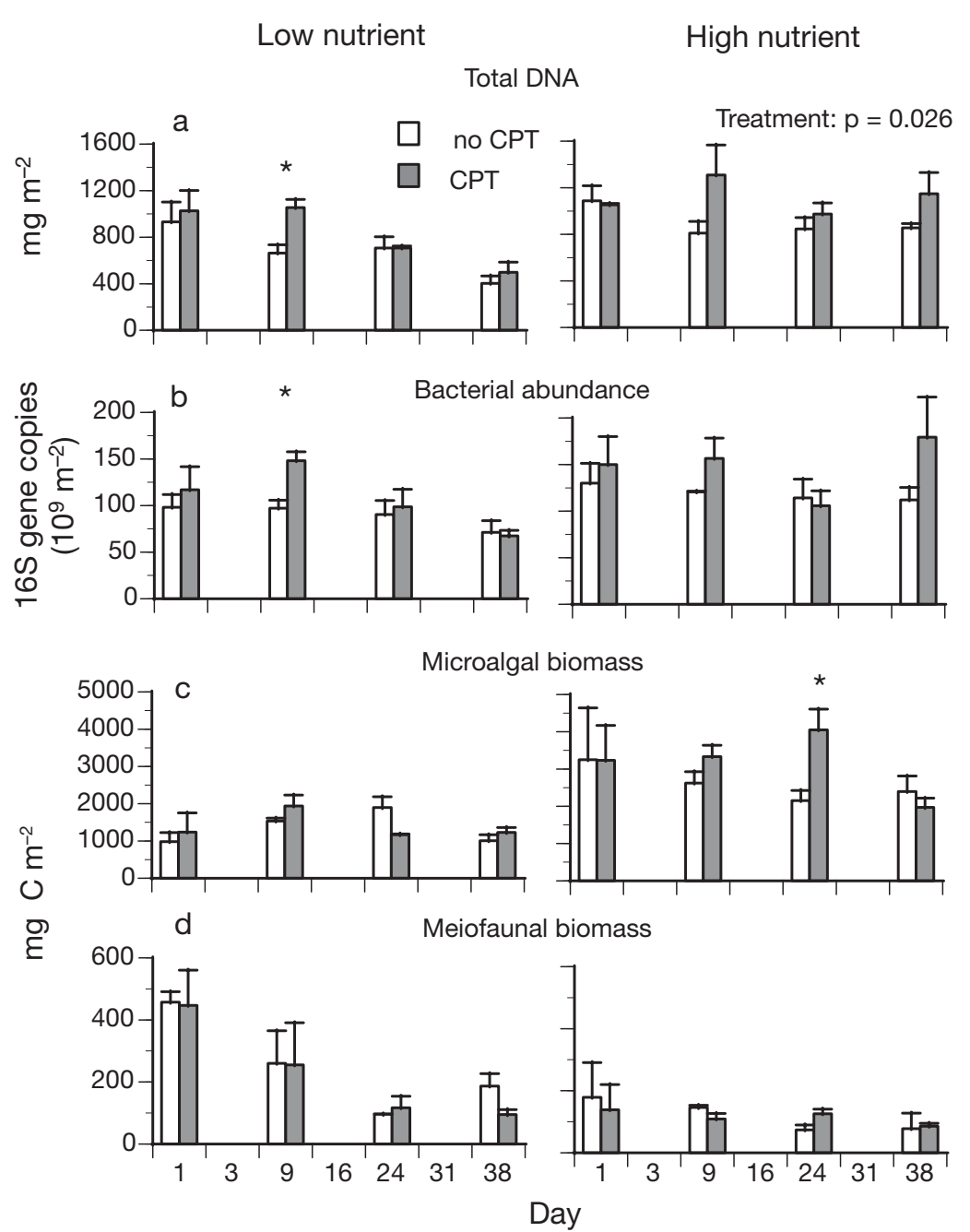

Fig. 5. Structural variables: (a) amount of total DNA, (b) bacterial abundance, (c) biomass of microalgae (converted to carbon from chl a assuming $\mathrm{C} / \mathrm{chl}$ a ratio of 30), and (d) meiofauna in $\mathrm{Nu}_{\text {low }}$ (left panels) and $\mathrm{Nu}_{\text {high }}$ treatments (right panels), with and without addition of copper pyrithione (CPT). Shown are means $+\mathrm{SE}(\mathrm{n}=3)$. Treatment: significant main treatment effect of CPT (2-way ANOVA, $\mathrm{p}=0.05) ;{ }^{*}$ : significant effect $(\mathrm{p}<0.05)$ of CPT for an individual day (SNK or 1-way ANOVA, p < 0.05)

$\mathrm{N}$ between nitrifiers and microalgae (RisgaardPetersen 2003) or to a direct toxic effect on denitrifying bacteria (Petersen et al. 2004). Generally, both denitrification rates $\left(0.1\right.$ to $\left.0.8 \mathrm{mmol} \mathrm{m}^{-2} \mathrm{~d}^{-1}\right)$ and $A: D$ ratios ( 10 to 200 ) were within the range earlier found for similar areas in cool Nordic waters (Sundbäck \& Miles 2000, Risgaard-Petersen 2003).

\section{Single and combined effects of CPT and nutrients}

Although our main goal was to evaluate the combined effects of nutrients and CPT, it is relevant to also consider single effects of the 2 treatments. The effect of the initial nutrient enrichment alone on functional variables was greater than that of CPT alone. The combination of nutrient enrichment and CPT affected more variables than CPT alone; in terms of the number of functional variables affected, the effect was about the same as for nutrient additions alone. It should be kept in mind that, while the sediment was exposed to a high nutrient concentration for $2 \mathrm{wk}$, the concentration of the CPT addition was low and only applied on 4 consecutive nights. Also Wiegner et al. (2003), who used mesocosms containing sieved sediment to study the effects of nutrients and trace metals (arsenic, copper, cadmium), found that the combination of trace metals and nutrients had more effects on system functions (e.g. respiration and NEM) than trace metals alone. As we found for $\mathrm{CPT}$, they noted that the effects of trace metals alone were lower and more variable than those of nutrients alone. But unlike our results, they also found that the treatments significantly affected NEM: nutrient addition alone increased autotrophy, trace metals alone increased heterotrophy, and so did the combination of nutrients and trace metals (but to a lesser extent than trace metals alone). Such an overall change in the trophic status never occurred in our sediment. The reason may be that our sediment system was initially highly autotrophic, whereas the system studied by Wiegner et al. (2003) was originally heterotrophic, but was pushed over to autotrophy by the nutrient addition.

\section{Complex interactive effects}

Our results show that nutrient-toxicant interactions are complex. None of the hypothetical scenarios of nutrient-toxicant interactions mentioned earlier can be generally applied to our results when the whole experimental period is considered, probably because of a mixture of direct and indirect effects (see below), as well as because nutrient and CPT effects were nonadditive. However, the initial toxicant effects do suggest that the nutrient-richer sediment system was initially more sensitive to CPT (decreased CR, denitri- 
Day 1

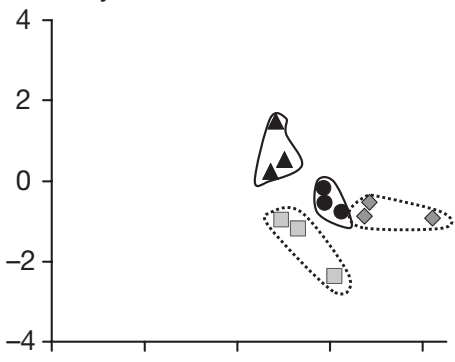

Day 3

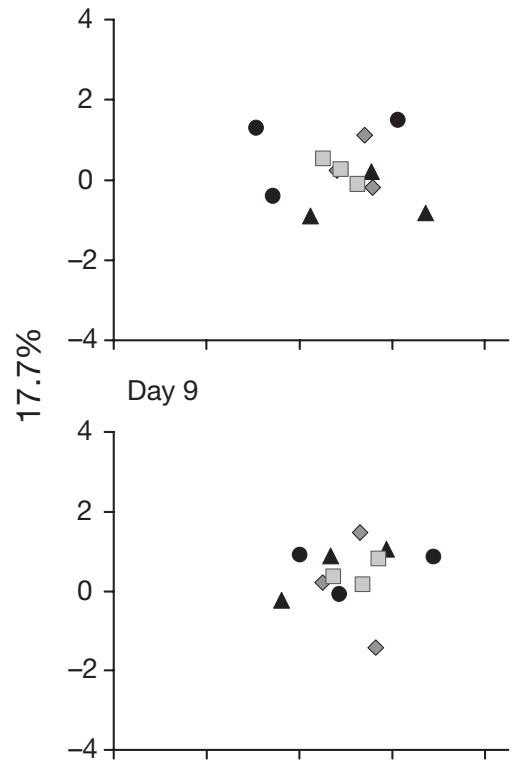

Day 16

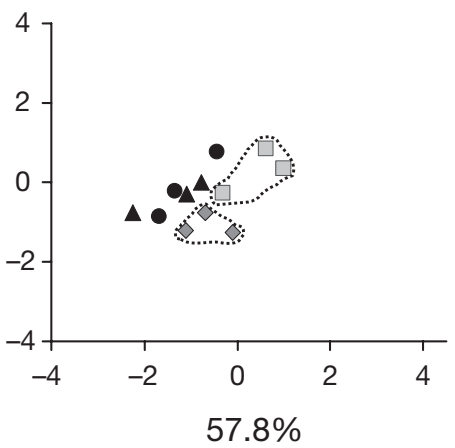

Day 24

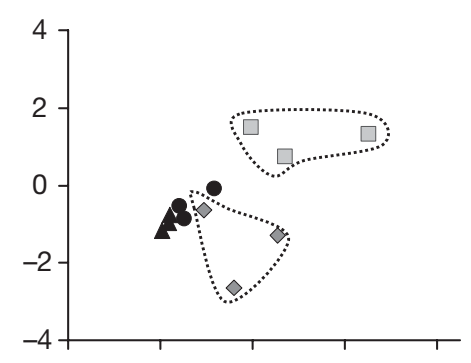

Day 31



Day 38

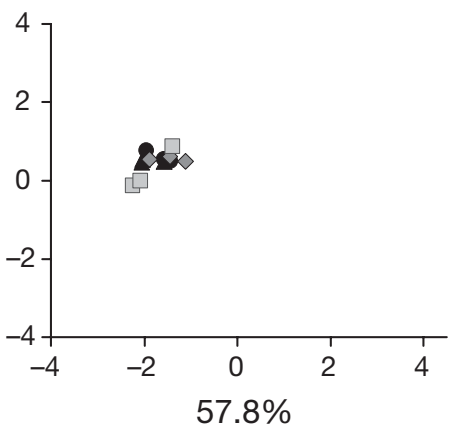

\section{$\Delta \mathrm{Nu}_{\mathrm{low}}$}

- $\mathrm{Nu}_{\text {low }} \mathrm{CPT}$

$\diamond \mathrm{Nu}_{\text {high }}$

$\square \mathrm{Nu}_{\text {high }} \mathrm{CPT}$

Fig. 6. Integrated system function analyzed by permutational multivariate analysis of variance (PERMANOVA) including 4 variables (NPP, CR, and $\mathrm{NO}_{3}{ }^{-}$ and $\mathrm{NH}_{4}{ }^{+}$fluxes, definitions see Table 1) depicted by a principal co-ordinate analysis plot. When the CPT treatment cluster differs significantly from the noCPT treatment, these clusters are encircled (see also Table 3). Percentage values for the 2 axes give the percent of total variation explained by the 2 co-ordinates

fication, DIN uptake, and DON efflux and increased efflux of $\mathrm{NH}_{4}^{+}$) than the nutrient-poor system, where fewer variables were affected (Table 2). This could, according to the hypothesis, be due to a higher metabolic rate of the enriched system or an inherently higher sensitivity to CPT. Breitburg et al. (1999) also found that the effect of trace metals increased when in combination with nutrient addition. Similarly, Doyle et al. (2005) found more effects of a stressor (ultraviolet radiation) on phytoplankton with higher nutrient availability. The more pronounced CPT effect in the $\mathrm{Nu}_{\text {high }}$ system in our experiment could also be caused by an increased sensitivity due to less favorable oxygen conditions during the night, as suggested by phosphate export in the high-nutrient sediment ( $F$. Larson et al. unpubl.). A third explanation could be that the potential of response to a stressor (and hence the detection of the response) is higher under nutrient-rich conditions (F. Larson et al. unpubl.).

Regarding the base of the food web of shallow-water sediments, the rather few existing studies on combined nutrient-stressor effects have generally found that nutrient-rich systems are less sensitive to stressors (Wulff et al. 2000, Laursen et al. 2002, Wiegner et al. 2003). This is in contrast to our results. Laursen et al. (2002) found that the effects of trace metals were higher in sandy, nutrient-poor sediments. However, they added the contaminant to the water column (not the sediment as we did), which negatively affected the plankton community, leading to stimulus of BMA due to improved light conditions. Then again, when comparing results from different experiments, it must be kept in mind that nutrientstressor effects may depend on the type of community studied, the species composition, the toxicant studied, as well as the season, which means that the timing of the experiment may be crucial for the outcome (Breitburg et al. 1999, Bundy et al. 2003, Maraldo \& Dahllöf 2004b, Doyle et al. 2005). We studied sediment with a well-developed, microalgal community dominated by pennate diatoms, which are often found to be resistant to various stressors (see subsection 'Resilience'). This may explain why no major negative effects on the basic level were observed at the low concentrations of CPT that were used in our experiment. Microalgal communities in early successional stages 




Fig. 7. Integrated system function analyzed by permutational multivariate analysis of variance (PERMANOVA) including 7 variables (NPP, CR, $\mathrm{NO}_{3}{ }^{-}, \mathrm{NH}_{4}{ }^{+}$, and DON fluxes, $\mathrm{BP}$, and denitrification, definitions see Table 1) depicted by a principal co-ordinate analysis plot. When the CPT treatment cluster differs significantly from the no-CPT treatment, these clusters are encircled (see also Table 3). Percentage values for the 2 axes give the percent of total variation explained by the 2 co-ordinates

have, on the other hand, been found to be susceptible to stressors, for example UV-B (Villafañe et al. 2003). Moreover, benthic diatom mats are rich in extracellular polymeric substances (e.g. Underwood et al. 1995), which may function as a protective barrier against toxic compounds, as well as enhance the uptake of
Table 3. Results from a 2-way permutational multivariate analysis of variance (PERMANOVA) and pair-wise a posteriori comparisons of the effects of copper pyrithione using 2 data sets. Analysis of the $7 \mathrm{~d}$ data set includes 4 variables (net primary production, community respiration, and ammonium and nitrate fluxes). The $4 \mathrm{~d}$ data set includes 3 additional variables (bacterial production, denitrification, and dissolved organic nitrogen flux). Significant $p$-values $(p \leq 0.05)$ are in bold print

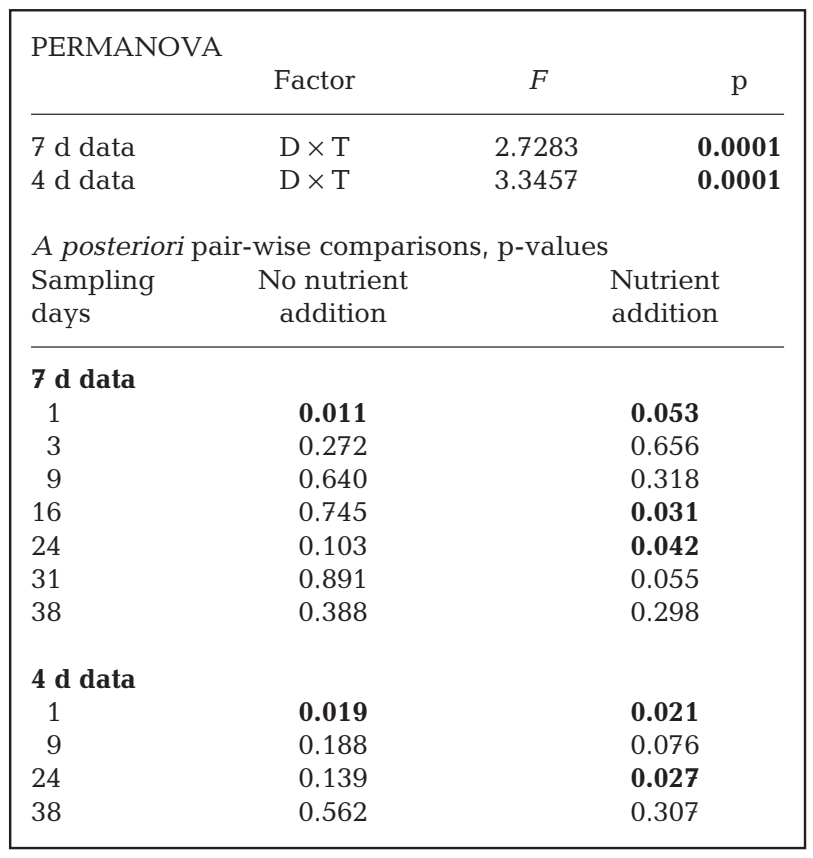

favorable compounds (Decho 1990). This feature could decrease the vulnerability of microbial mats to toxic compounds. Piehler et al. (2003) concluded that benthic microalgae were less sensitive to diesel fuels than were phytoplankton and epiphytic algae in the same area. Thus, it appears that the response of primary producers in sediments cannot be predicted from the outcome of experiments on the pelagic system.

The pattern of effects in the $\mathrm{Nu}_{\text {high }}$ system later during the experiment (higher primary production, algal biomass, and ammonium uptake) suggests that initial effects were followed by a sequence of indirect effects (note that some effects were, however, reversed towards the end of the experiment). Indirect food-webmediated effects may indeed become more significant than direct toxicant effects, particularly at low concentrations of a toxicant with a short half-life, as in our study (Preston 2002, Fleeger et al. 2003, Chapman 2004). The observed stimulus of bacterial production in the middle of the experiment in the $\mathrm{Nu}_{\text {high }}$ treatment could be an effect of rapid recycling of nutrients and carbon from the stimulated primary producers to bacteria. This is indicated by strong positive correlations of BP with both GPP $(r=0.74, p=0.001)$ and NPP $(r=0.73$, $\mathrm{p}=0.001$ ) and by positive correlation between bacterial 
biomass and chl a $(\mathrm{r}=0.73, \mathrm{p}=0.001)$. Generally, the exudation of organic material from algae to bacteria may, in fact, have a more pronounced role in the benthic system than in the microbial loop of the pelagic system (Goto et al. 1999, Tobias et al. 2003), particularly in microbial mats as thick as those in our experiment.

In pelagic systems, toxicant impacts are often considered to be transferred from the lowest trophic level (algae) to higher trophic levels (Breitburg et al. 1999, Bundy et al. 2003, Brock et al. 2004). In our benthic system, however, top-down effects may also have been important. Thus, the observed stimulus from CPT on microalgae in the $\mathrm{Nu}_{\text {high }}$ treatment observed in the middle of the experiment may have been caused by larger CPT effects on grazers (including their behavior) than on their prey, although we cannot with certainty establish the causal links. Similar effects from grazers on benthic microalgae have been found when studying effects of hydrocarbon contaminants (Carman et al. 1997) and UV-B (Bothwell et al. 1994). As Chapman (2004) points out, accurate predictions of the role of indirect effects require a good understanding of functional interactions along food chains. Hence, measuring grazing pressure could have been a useful explanatory variable in our experiment.

\section{Resilience}

For those individual functional variables that were affected by $\mathrm{CPT}$ in the $\mathrm{Nu}_{\text {high }}$ system $\left(\mathrm{CR}, \mathrm{NH}_{4}{ }^{+}\right.$flux, denitrification), effects remained through the later part of the experiment. Although the multivariate analysis suggests that integrated system function had recovered after 3 to $5 \mathrm{wk}$, we cannot exclude the possibility that the system functions continued to fluctuate, particularly in the sediment with higher nutrient status. Thus, the time scale of resilience experiments is crucial, particularly since different species operate on different temporal and spatial scales (Peterson et al. 1998, Paerl \& Steppe 2003). The sampling design of our study was based on experiences from previous experiments on the effect of single stressors on microbiota in similar sediments and where recovery occurred within a period of days or a few weeks (Sundbäck et al. 1990, Sloth et al. 1996, Wulff et al. 1997, F. Larson unpubl. data, F. Larson \& K. Sundbäck unpubl. data). In retrospect, it would have been advantageous to carry out a longer experiment, or to use one more concentration of CPT addition. However, such an extended design would have required a larger system or fewer occasions of destructive sampling. It needs to be pointed out that the water flowing through our set-up was not filtered, and immigration - possibly acting to decrease resilience time - was not excluded. On the other hand, the fact that temperature and light levels sank towards the end of our CPT experiment may have slowed down system metabolism, decreasing its resilience.

Benthic diatoms were the dominating photoautotrophs in our system (F. Larson et al. unpubl.), and may have had an important role in the recovery. In previous studies, benthic diatoms have been shown to contribute to a rapid system-level recovery after a temporary disturbance. They are tolerant to low light levels (and even periods of darkness), anoxia, and sulfides (Admiraal 1984, Kennett \& Hargraves 1985, Sundbäck \& Granéli 1988, Sundbäck et al. 1990). When resuming their photosynthetic activity after the disturbance, they quickly restore the oxygenation of the sediment surface (Sundbäck et al. 1990, Wulff et al. 1997, F. Larsson $\&$ K. Sundbäck unpubl. data), contributing to the overall resilience of shallow-water sediment systems.

While processes related to primary producers appeared resilient, those related to bacterial nitrogen turnover (denitrification, ammonium flux) showed a slower recovery. Also others have found that bacterial $\mathrm{N}$-turnover processes in sediments may be sensitive (Joye \& Hollibaugh 1995). Similarly, Holmer et al. (1997) found that sulfate reduction was more affected by fluoranthene than was oxygen flux. The observed higher sensitivity of $\mathrm{N}$ processes is also in accordance with the results for terrestrial soils, where functional redundancy for nitrification and denitrification was low (Griffiths et al. 2000, Cavigelli \& Robertson 2001). Thus, to understand the response and resilience of sediment ecosystems, it is important to consider not only general indicators, such as oxygen production and the net direction of DIN flux, but also more specific turnover processes, where functional redundancy may be lower. Moreover, because producer-decomposer co-dependence is likely to occur in natural sediment systems, the simultaneous analysis of the function and structure of both primary producers and decomposers is highly relevant (cf. Naeem et al. 2000).

\section{Conclusions}

Our results show that effects of a short-term, lowlevel exposure to non-persistent CPT can be traced in shallow-water sediments. The response of particular functional variables can be affected by the nutrient status of the system. Moreover, although basic systemlevel properties (such as trophic status and the net direction of sediment-water nitrogen flux) may not appear to be strongly affected by a short-term, lowlevel addition of the toxicant, individual processes (community respiration, ammonium flux, and denitrification) can be significantly affected. The combined nutrient-CPT effect appears to be a combination of 
initial toxic effects and a consecutive sequence of indirect effects, probably mediated by food-web effects, such as changed grazing pressure. The effects of shortterm CPT exposure can remain for weeks, and a higher nutrient status may prolong the recovery time of the sediment system. A high degree of autotrophy, with benthic microalgae dominating carbon and nutrient cycling, may, on the other hand, function to a certain degree as a buffering mechanism, mitigating the overall response of illuminated sediments and increasing resilience. Measuring only general metabolic indicators may be inadequate to detect combined nutrienttoxicant effects on sediment systems. In the case of nitrogen cycling, individual processes have to be considered because they may vary in sensitivity and resilience. Thus, to understand system-level response and resilience of illuminated sediments, simultaneous analysis of the structure and function, including foodweb interactions, of both primary producers and decomposers is crucial. The overall ecological interpretation of our observations is that, while single CPT exposure events may not alter general metabolic function (oxygen flux) - at least not in net autotrophic sediments-repeated CPT exposure of the sediment microbiota may have a significant impact on the $\mathrm{N}$ cycling in shallow, eutrophied waters.

Acknowledgements. Funding was received from the Swedish Research Council (VR), the Swedish Research Council for Environment, Agricultural Sciences and Special Planning (FORMAS), the Marine Research Centre of Göteborg University, Nordic Council of Ministers, the Royal Society of Arts and Sciences in Göteborg, the Memorial Fund of Birgit and Birger Wåhlström, the Captain Stenholm Fund, the Letterstedtska Foundation, and the Family Hede Nielsen Foundation. We thank M. Hjorth, R. Haller, D. W. Jensen (National Environmental Research Institute of Denmark); L. P. Nielsen and T. L. Skovhus (University of Aarhus); and the crew of RV 'Oscar von Sydow', Kristineberg Marine Research Station, for assistance. Arch Chemicals kindly supplied copper pyrithione, but had no further part in the project. We thank 2 anonymous referees, whose constructive comments substantially improved the manuscript.

\section{LITERATURE CITED}

Adams SM (2005) Assessing cause and effect of multiple stressors on marine systems. Mar Pollut Bull 51:649-657

Admiraal W (1984) The ecology of estuarine sediment-inhabiting diatoms. In: Round F, Chapman DJ (eds) Progress in phycological research, Vol 3. Biopress, Bristol, p 269-322

Anderson MJ (2001) A new method for non-parametric multivariate analysis of variance. Aust Ecol 26:32-46

Anderson MJ (2003) PCO: a FORTRAN computer program for principal coordinate analysis. Department of Statisics, University of Auckland

Anderson MJ (2004) PERMDISP: a FORTRAN computer program for permutational analysis of multivariate dispersion (for any two-factor ANOVA design) using permutation test. Department of Statistics, University of Auckland
Anderson MJ (2005) PERMANOVA: a FORTRAN computer program for permutational multivariate analysis of variance. Department of Statistics, University of Auckland

Bothwell ML, Sherbot DMJ, Pollock CM (1994) Ecosystem response to solar ultraviolet-B radiation: influence of trophic-level interactions. Science 265:97-100

Breitburg DL, Sanders JG, Gilmour CC, Hatfield CA, Osman RW, Riedel GFS, Seitzinger SP, Sellner KG (1999) Variability in responses to nutrients and trace elements, and transmission of stressors effect through an estuarine food web. Limnol Oceanogr 44:837-863

Brock TCM, Crum SJH, Deener JW, Heimbach F, Roijackers RMM， Sinkeldam JA (2004) Comparing aquatic risk assessment methods for the photosynthesis-inhibiting herbicides metribuzin and metamitron. Environ Pollut 130: 403-426

Bundy MH, Breitburg DL, Sellner KG (2003) The responses of Patuxent River upper trophic levels to nutrient and trace element induced changes in the lower food web. Estuaries 26:365-384

Carman KR, Fleeger JW, Pomarico SM (1997) Response of a benthic food web to hydrocarbon contamination. Limnol Oceanogr 42:561-571

Cavigelli MA, Robertson GP (2001) Role of denitrifier diversity in rates of nitrous oxide consumption in a terrestrial ecosystem. Soil Biol Biochem 33:297-310

Chapman PM (2004) Indirect effects of contaminants. Mar Pollut Bull 48:411-412

Conley DJ, Markager S, Andersen J, Ellermannn T, Svendsen LM (2002) Coastal eutrophication and the Danish National Aquatic Monitoring and Assessment Program. Estuaries 25:848-861

Dalsgaard T, Nielsen LP, Brotas V, Viaroli P and 11 others (2000) Protocol handbook for NICE - nitrogen cycling in estuaries: a project under the EU research programme: Marine Science and Technology (MAST III). National Environmental Research Institute, Silkeborg

Decho AW (1990) Microbial exopolymer secretions in ocean environments: their role(s) in food webs and marine processes. Oceanogr Mar Biol Annu Rev 28:73-153

de Jonge VN (1980) Fluctuations in the organic carbon to chlorophyll a ratios for estuarine benthic diatom populations. Mar Ecol Prog Ser 2:345-353

de Wit R, Stahl LJ, Lomstein BA, Herbert RA and 18 others (2001) ROBUST: the ROle of BUffering capacities in STabilising coastal lagoon ecosystems. Cont Shelf Res 21: 2021-2041

Dinning AJ, Al-Adham ISI, Eastwood IM, Austin P, Collier PJ (1998) Pyrithione biocides as inhibitors of bacterial ATP synthesis. J Appl Microbiol 85:141-146

Doyle SH, Saros JE, Williamson CE (2005) Interactive effects of temperature and nutrient limitation on the response of alpine phytoplankton growth to ultraviolet radiation. Limnol Oceanogr 50:1362-1367

Fear J, Gallo T, Hall N, Loftin J, Paerl H (2004) Predicting benthic microalgal oxygen and nutrient flux responses to a nutrient reduction management strategy for the eutrophic Neuse River Estuary, North Carolina. Estuar Coast Shelf Sci 61:491-506

Fleeger JW, Carman KR, Nisbet RM (2003) Indirect effects of contaminants in aquatic ecosystems. Sci Total Environ 317:207-233

Glud RN, Kühl M, Wenzhöfer F, Rysgaard S (2002) Benthic diatoms of a high Arctic fjord (Young Sound, NE Greenland): importance for ecosystem primary production. Mar Ecol Prog Ser 238:15-29

Goto N, Kawamura T, Mitamura O, Terai H (1999) Importance 
of extracellular organic carbon production in the total primary production by tidal-flat diatoms in comparison to phytoplankton. Mar Ecol Prog Ser 190:289-295

Griffiths BS, Ritz K, Bardgett RD, Cook R and 8 others (2000) Ecosystem response of pasture soil communities to fumigation-induced microbial diversity reductions: an examination of the biodiversity-ecosystem function relationship. Oikos 90:279-294

Grimm V, Wissel C (1997) Babel, or the ecological stability discussions: an inventory and analysis of terminology and a guide for avoiding confusion. Oecologia 109:323-334

Grunnet KS, Dahllöf I (2005) Environmental fate of the antifouling compound zinc pyrithione in seawater. Environ Toxicol Chem 24:3001-3006

Heugens EHW, Hendriks AJ, Dekker T, van Straalen NM, Admiraal W (2001) A review of the effects of multiple stressors on aquatic organisms and analysis of uncertainty factors for use in risk assessment. Crit Rev Toxicol 31: $247-284$

Hillebrand H, Kahlert M (2002) Effect of grazing and water column nutrient supply on biomass and nutrient content of sediment microalgae. Aquat Bot 72:143-159

Holmer M, Forbes VE, Forbes TL (1997) Impact of the polychaete Capitella sp. on microbial activity in an organicrich marine sediment contaminated with the polycyclic aromatic hydrocarbon fluoranthene. Mar Biol 128: 679-688

Interlandi SJ (2002) Nutrient-toxicant interactions in natural and constructed phytoplankton communities: results of experiments in semi-continuous and batch culture. Aquat Toxicol 61:35-51

Joye SB, Hollibaugh JT (1995) Influence of sulfide inhibition of nitrification on nitrogen regeneration in sediments. Science 270:623-625

Kennett DM, Hargraves PE (1985) Benthic diatoms and sulfide fluctuations: upper basin of Pettaquamscutt River, Rhode Island. Estuar Coast Shelf Sci 21:577-586

Kirk JTO (1994) Light and photosynthesis in aquatic ecosystems. Cambridge University Press, Cambridge

Koelmans AA, van der Heijde A, Knijff LM, Aalderink RH (2001) Integrated modelling of eutrophication and organic contaminant fate and effects in aquatic ecosytems. A review. Wat Res 35:3517-3536

La Rosa T, Mirto S, Mazzola A, Danovaro R (2001) Differential responses of benthic microbes and meiofauna to fish-farm disturbance in coastal sediments. Environ Pollut 112: 427-434

Laursen AE, Seitzinger SP, DeKorsey R, Sanders JG, Breitburg DL, Osman RW (2002) Multiple stressors in an estuarine system: effects of nutrients, trace elements, and trophic complexity on benthic photosynthesis and respiration. Estuaries 25:57-69

Lorenzen CJ (1967) Determination of chlorophyll and pheopigments: spectrophotometric equations. Limnol Oceanogr 12:343-346

Maraldo K, Dahllöf I (2004a) Indirect estimation of degradation time for zink pyrithione and copper pyrithione in seawater. Mar Pollut Bull 48:894-901

Maraldo K, Dahllöf I (2004b) Seasonal variations in the effect of zinc pyrithione and copper pyrithione on pelagic phytoplankton communities. Aquat Toxicol 69:189-198

McArdle BH, Anderson MJ (2001) Fitting multivariate models to community data: a comment on distance based redundancy analysis. Ecology 82:290-297

McGlathery K, Sundbäck K, Anderson IC (2004) The importance of primary producers for benthic nitrogen and phosphorus cycling. In: Nielsen SL, Banta GT, Pedersen MF (eds) Estuarine nutrient cycling: the influence of primary producers. The fate of nutrients and biomass. Aquat Ecol $2: 232-262$

Naeem S, Hahn DR, Schuurman G (2000) Producerdecomposer co-dependence influences biodiversity effects. Nature 403:762-764

Nielsen LP (1992) Denitrification in sediment determined from nitrogen isotope pairing. FEMS Microbiol Ecol 86: 357-362

Nielsen SL, Banta GT, Pedersen MF (eds) (2004) Estuarine nutrient cycling: the influence of primary producers. The fate of nutrients and biomass. Aquatic ecology series No. 2. Kluwer Academic, Dordrecht

Nilsson P, Jönsson B, Lindström Swanberg I, Sundbäck K (1991) Response of a marine shallow-water sediment system to an increased load of inorganic nutrients. Mar Ecol Prog Ser 71:275-290

Paerl HW, Steppe TF (2003) Scaling up: the next challenge in environmental microbiology. Environ Microbiol 5: 1025-1038

Petersen DG, Dahllöf I (2005) Improvements for comparative analysis of changes in diversity of microbial communities using internal standards in PCR-DGGE. FEMS Microb Ecol 53:339-348

Petersen DG, Dahllöf I, Nielsen LP (2004) Effects of zinc pyrithione and copper pyrithione on microbial community function and structure in sediments. Environ Toxicol Chem 23:921-928

Peterson G, Allen CR, Holling CS (1998) Ecological resilience, biodiversity, and scale. Ecosystems 1:6-18

Piehler MF, Winkelmann V, Twomey LJ, Hall NS, Currin CA, Pearl HW (2003) Impacts of diesel fuel exposure on the microphytobenthic community of an intertidal sand flat. J Exp Mar Biol Ecol 297:219-237

Preston BL (2002) Indirect effects in aquatic ecotoxicology. Implications for ecological risk assessment. Environ Manage 29:311-323

Risgaard-Petersen N (2003) Coupled nitrification-denitrification in autotrophic and heterotrophic estuarine sediments: on the influence of benthic microalgae. Limnol Oceanogr 48:93-105

Sheridan P (2004) Recovery of floral and faunal communities after placement of dredged material on seagrasses in Laguna Madre Texas. Estuar Coast Shelf Sci 59:441-458

Simon M, Azam F (1989) Protein content and protein synthesis rates of planktonic marine bacteria. Mar Ecol Prog Ser 51:201-213

Skovhus TL, Ramsing NB, Holmstrom C, Kjellebreg S, Dahllöf I (2004) Real-time quantitative PCR for assessment of abundance of Pseudoalteromonas species in marine samples. Appl Environ Microbiol 70:2373-2382

Sloth NP, Riemann B, Nielsen LP, Blackburn TH (1996) Resilience of pelagic and benthic microbial communities to sediment resuspension in a coastal ecosystem, Knebel Vig, Denmark. Estuar Coast Shelf Sci 42:405-415

Sundbäck K, Granéli W (1988) Influence of microphytobenthos on the nutrient flux between sediment and water: a laboratory study. Mar Ecol Prog Ser 43:63-69

Sundbäck K, McGlathery K (2005) Interactions between benthic macroalgal and microalgal mats. In: Kristensen E, Haese RH, Kostka JE (eds) Interactions between macro- and microorganisms in marine sediments. AGU series coastal and estuarine studies 60, Washington, DC, p 7-29

Sundbäck K, Miles A (2000) Balance between denitrification and microalgal incorporation of nitrogen in microtidal sediments, NE Kattegat. Aquat Microb Ecol 22:291-300 
Sundbäck K, Jönsson B, Nilsson P, Lindström I (1990) Impact of accumulating drifting macroalgae on a shallow-water sediment system: an experimental study. Mar Ecol Prog Ser 58:261-274

Thrush SF, Dayton PK (2002) Disturbance to marine benthic habitats by trawling and dredging: implications for marine biodiversity. Annu Rev Ecol Syst 33:449-473

Tobias C, Giblin A, McClelland J, Tucker J, Peterson B (2003) Sediment DIN fluxes and preferential recycling of benthic microalgal nitrogen in a shallow macrotidal estuary. Mar Ecol Prog Ser 257:25-36

Underwood AJ (1997) Experiments in ecology: their logical design and interpretation using analysis of variance. Cambridge University Press, Cambridge

Underwood GJC, Kromkamp J (1999) Primary production by phytoplankton and microphytobenthos in estuaries. Adv Ecol Res 29:93-153

Underwood GJC, Paterson DM (1993) Recovery of intertidal benthic diatoms after biocide treatment and associated sediment dynamics. J Mar Biol Assoc UK 73:25-45

Underwood GJC, Paterson DM, Parkes RJ (1995) The measurement of microbial carbohydrate exopolymers from intertidal sediments. Limnol Oceanogr 40:12431253

Villafañe V, Sundbäck K, Figueroa FL, Helbling EW (2003) Photosynthesis in the aquatic environment as affected by ultraviolet radiation. In: Helbling EW, Zagarese H (eds)

Editorial responsibility: Victor de Jonge (Contributing Editor), Haren, Netherlands
UV effects in organisms and ecosystems. Compr Ser Photochem Photobiol 1:357-307

Vinebrook RD, Cottingham KL, Norberg J, Scheffer M, Dodson SI, Maberly SC, Sommer U (2004) Impacts of multiple stressors on biodiversity and ecosystem functioning: the role of species co-tolerance. Oikos 104:451-457

Wetzel MA, Weber A, Giere O (2002) Re-colonization of anoxic/sulfidic sediments by marine nematodes after experimental removal of macroalgal cover. Mar Biol 141:679-689

Widbom B (1984) Determination of average individual dry weights and ash-free dry weights in different sieve fractions of marine meiofauna. Mar Biol 75:101-109

Wiegner TN, Seitzinger SP, Breitburg DL, Sanders JG (2003) The effects of multiple stressors on the balance between autotrophic and heterotrophic processes in an estuarine system. Estuaries 26:352-364

Worm B, Reusch TBH, Lotze HK (2000) In situ nutrient enrichment: methods for marine benthic ecology. Int Rev Hydrobiol 85:359-375

Wulff A, Sundbäck K, Nilsson C, Carlson L, Jönsson B (1997) Effect of sediment load on the microbenthic community of a shallow-water sandy sediment. Estuaries 20:547-558

Wulff A, Wängberg SÅ, Sundbäck K, Nilsson C, Underwood G (2000) Effects of UVB radiation on a marine microphytobenthic community growing on a sand-substratum under different nutrient conditions. Limnol Oceanogr 45: $1144-1152$

Submitted: May 30, 2005; Accepted: June 17, 2006

Proofs received from author(s): January 12, 2007 